\title{
Energy and Exergy Analyses of an Open Thermochemical Energy Storage System: Methodology and Illustrative Application
}

\author{
Ali Haji Abedin and Marc A. Rosen* \\ Faculty of Engineering and Applied Science University of Ontario Institute of Technology Oshawa, Ontario, L1H 7K4, \\ Canada
}

\begin{abstract}
Thermal energy storage (TES) is a developed technology for storing thermal energy that can diminish environmental impacts and provide more efficient and environmentally friendly energy systems. Among various types of TES systems, thermochemical TES is an advanced method with the potential for higher energy storage densities and more compact systems. The evaluation of such systems is improved significantly when exergy analysis is used to complement energy analysis. Here, a general open thermochemical TES is investigated using energy and exergy analyses. An example using experimental data is presented to illustrate the analyses. Efficiencies are determined for the overall TES cycle and its charging, storing and discharging processes. The overall energy and exergy efficiencies for system considered in the illustrative example are determined to be $69 \%$ and $23 \%$, respectively. This result indicates that the efficiency of the thermochemical TES based on exergy is much lower than that based on energy, and that there is a significant margin for loss reduction and efficiency improvement.
\end{abstract}

Keywords: Thermal energy storage, thermochemical energy storage, exergy, energy efficiency, exergy efficiency, first law efficiency, second law efficiency.

\section{INTRODUCTION}

Societal energy demands are presently increasing while fossil fuel resources, which dominate most national energy systems, are limited and predicted to become scarcer and more expensive in coming years $[1,2]$ Furthermore, many concerns exist regarding the environmental impacts associated with increasing energy consumption, such as climate change and atmospheric pollution. Greenhouse gas (GHG) emissions are considered the main cause of climate change, and agreements to limit them, such as the Kyoto Protocol, have been developed [3].

Thermal energy storage (TES) systems are one of developed technologies that can provide to achieve advanced energy systems. There are three main types of TES: sensible, latent and chemical [4]. Sensible TES systems store energy by changing the temperature of the storage medium. Latent TES systems store energy through phase change. In thermochemical energy storage, energy is stored after a dissociation reaction and then recovered in a chemically reversed reaction. Thermochemical energy storage has a higher storage density than the other types of TES, allowing large quantities of energy to be stored using small amounts of storage substances. Thermochemical TES systems can be classified as closed or open [5]. In closed systems, internal substances are separate from the heat transport fluid while in open systems, internal substances are not separate from the heat transport fluid. Closed systems can provide higher output temperature than open systems in heating applications [6]. Charging

*Address correspondence to this author at the Faculty of Engineering and Applied Science, University of Ontario Institute of Technology; Canada Tel: 905/721-5726; Fax: 905/721-3370; E-mail: marc.rosen@uoit.ca. processes in closed systems usually need higher temperatures than open systems [7]. In open thermochemical energy storage, the basic operating principle is the same as for closed thermochemical TES. The main chemical reaction can be expressed as follows:

$C+$ heat $\leftrightarrows A+B$

In this reaction, a thermochemical material (TCM) absorbs energy and is converted chemically into two components (A and B), which can be stored separately. The reverse reaction occurs when $\mathrm{A}$ and $\mathrm{B}$ are combined together and $\mathrm{C}$ is formed. Energy is released during this reaction and constitutes the recovered thermal energy from the TES. The storage capacity of this system is the heat of reaction when $\mathrm{C}$ is formed.

In open thermochemical TES, the heat transport fluid is not separate from materials A, B and C. Open thermochemical TES systems operate in an open loop coupled to the ambient conditions and an air stream transports water vapor and heat in and out of the packed bed of thermochemical materials [8]. Open sorption storage is a type of open thermochemical TES. Open sorption systems operate at the atmospheric pressure and the working fluid vapor is released to the environment $[8,9]$. Two examples of applications of open sorption TES in energy systems follow. Sorption systems in the Monosorp project have been examined by the Institute of Thermodynamics and Thermal Engineering at the University of Stuttgart [10]. Sorption energy storage as part of a district heating grid in Munich [11] has been studied by the Bavarian Center for Applied Energy Research (ZAE Bayern).

In this study, a detailed investigation based on energy and exergy is carried out of an open thermochemical TES. The objective is to improve understanding of the technology, 


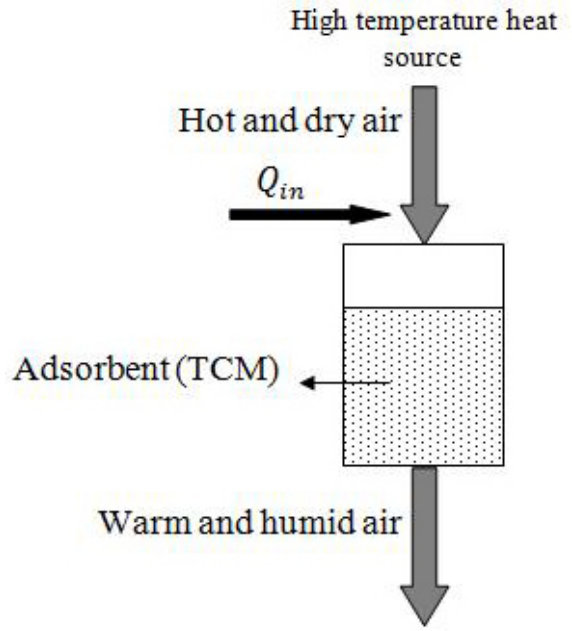

Fig. (1). Desorption process in open thermochemical TES. Adapted from [11].

so as to facilitate its development. An illustrative example is included based on experimental data from the open literature.

\section{ENERGY AND EXERGY ANALYSES}

A general open thermochemical TES is considered and energy and exergy analyses are performed. The system considered, consists of a working fluid (air) and a thermochemical material. Thermal energy from an energy supply (e.g. a district heating system) is transferred to air and provides the energy necessary for desorption of the thermochemical material. After a storing period, energy released from adsorption of the thermochemical material warms air to be used for heating purposes.

This analysis is limited to open TES systems where internal substances are not separate from the heat transport fluid. The following assumptions are made in this investigation:

- Chemical reactions within the reactor occur at constant pressure.

- Work interactions into and out of the control volume are neglected, as are kinetic and potential energy. The former assumption implies that pump, compressor and fan work are neglected.

- The physical exergy change of the components is neglected relative to their chemical exergy changes.

\subsection{Charging (Desorption) Process}

A general charging process for an open thermochemical TES is illustrated in Fig. (1). A hot air stream is heated by a high temperature heat source, and flows through the storage. There, the hot air stream desorbs the water from the adsorbent (thermochemical material) and dries it, after which it exits the packed bed a lower temperature and a higher humidity. The process is endothermic and the net energy input to the packed bed $Q_{\text {in }}$ is supplied by the input air.

\subsubsection{Energy Analysis for Charging}

A general energy balance for the charging process of a TES can be written as [12]:

Energy input - Energy output $=$ Energy accumulation

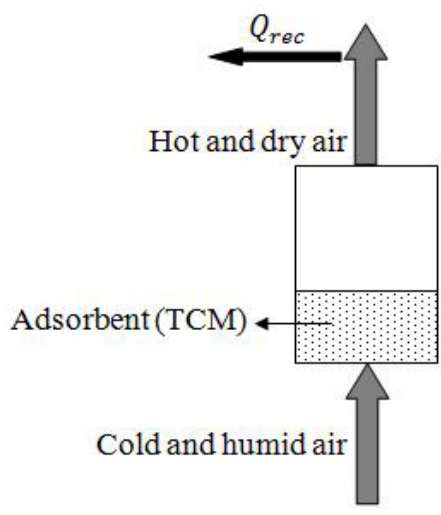

Fig. (2). Adsorption process in open thermochemical TES. Adapted from [11].

The net input energy is supplied by the air flow for this system. An energy balance for the charging process can be written as follows:

Net energy input - Heat loss = Energy accumulation in TES

or

$Q_{\text {in }}-Q_{i}=\Delta H d s$

where $Q_{\text {in }}$ is the net energy input to the system during the charging process and $Q_{i}$ denotes the total heat loss. The term $\Delta H d s$ is the enthalpy change of the desorption process.

The energy efficiency of the charging process can be expressed as follows:

$\eta_{c}=\frac{\text { Energy gained by adsorbent }}{\text { Energy input }}=\frac{\Delta H_{d s}}{\Delta Q_{i n}}$

\subsubsection{Exergy Analysis for Charging}

A general exergy balance for this system can be written as

Exergy input - Exergy loss - Exergy destruction = Exergy accumulation

or

$\in_{{ }_{i n}-} \in{ }_{l-} \in{ }_{D}=\Delta \in{ }_{d s}$

Here,

$\varepsilon_{\text {in }}$ Energy input $=$ Net energy delivered by air

Also, $\in_{D}$ denotes the exergy destruction, $\in \in_{l}$ the exergy loss, and $\Delta \in d s$ the exergy accumulation in the charging process.

We can evaluate the exergy efficiency of the charging process as follows:

$\Psi_{c}=\frac{\text { Exergy stored in desorption }}{\text { Exergy input }}=\frac{\Delta \epsilon_{d s}}{\epsilon_{\text {in }}}$

\subsubsection{Storing Process}

According to the assumptions made for the storing process, energy and exergy efficiencies of the storing process are equal to unity. 


\subsection{Discharging (Adsorption) Process}

A general discharging process for an open thermochemical TES is illustrated in Fig. (2). The previously humidified, cool indoor air enters the desorbed packed bed. Then, the adsorbent adsorbs water vapor from the air flow and releases the heat of adsorption $(\mathrm{Qrec})$. The process is exothermic.

\subsubsection{Energy Analysis for Discharging}

We can write an energy balance for the discharging period for a TES as follows [12]:

-[Energy recovered + Heat Loss $]=$ Energy accumulation

The recovered energy is gained by the air flow for this process. We can evaluate the energy efficiency of this process as follows:

$$
\eta_{d}=\frac{\text { Energy recovered }}{\text { Energy relaesed in adsorption }}=\frac{\mathrm{Q}_{\mathrm{rec}}}{\Delta H_{a d}}
$$

\subsubsection{Exergy Analysis for Discharging}

We can write an exergy balance for the discharging process as follows:

$-($ Exergy recovered + Exergy loss $)-$ Exergy destruction $=$ Exergy accumulation

or

$-\left(\in_{r c c} \in i\right)-\in D=\Delta \in a d$

Here,

$\varepsilon_{\text {rec }}=$ Exergy recovered $=$ Net Exergy recovered by air

where $\Delta \in$ ad denotes the exergy accumulation in the discharging process. We can evaluate the exergy efficiency of this process as

$$
\psi_{d}=\frac{\text { Exergy recovered by air }}{\text { Exergy released in adsorption }}=\frac{\Delta \in_{r c}}{\Delta \in a d}
$$

\subsection{Overall Process}

The energy and exergy analyses of the overall processes are considered in this section.

\subsubsection{Energy Analysis and Efficiency for Overall Process}

An energy balance for the overall open thermochemical storage process can be written as

$$
Q_{i n}-Q_{r e c}-Q_{i, t o t}=\Delta E
$$

For the case of a complete cycle with identical initial and final states, $\Delta E=0$. The energy efficiency for the overall storage process can be written as follows:

$\eta_{o}=\frac{\text { Energy recovered from TES during adsorption }}{\text { Energy output to TES during desorption }}=\frac{Q_{\text {rec }}}{Q_{i n}}$

\subsubsection{Exergy Analysis and Efficiency for Overall Process}

An exergy balance for the overall storage process can be written as

$\in_{\text {in }-} \in{ }_{\text {rec }} \in \in_{i, \text { tot }} \in \in_{D, \text { tot }}=\Delta \in$
For the case of a complete cycle with identical initial and final states, $\Delta \in=0$. The exergy efficiency for the overall storage process can be expressed as follows:

$\Psi_{\mathrm{o}}=\frac{\text { Exergy recovered from TES during adsorption }}{\text { Exergy output to TES during desorption }}=\frac{\epsilon_{\text {rec }}}{\epsilon_{\text {in }}}$

\section{ILLUSTRATIVE EXAMPLE}

To illustrate the analysis of an open thermochemical TES system, we consider an existing system for which experimental data have been reported.

\subsection{System Description}

An open sorption system has been utilized in a school in Munich, Germany since 1996. This system is connected to the district heating net. This thermochemical storage uses zeolite 13X as the adsorbent and can provide heating in winter as well as an air conditioning possibility in summer. This system is used to heat a school building in winter and cool a jazz club in summer. Both the school building and jazz club are connected to the Munich district heating system. The storage system is connected to a combined air, radiator and floor heating system [11]. The storage contains $7000 \mathrm{~kg}$ of zeolite $13 \mathrm{X}$ beads. Zeolite $13 \mathrm{X}$ is non-toxic and nonflammable and can be handled easily. The maximum air flow through the zeolite storage is $6000 \mathrm{~m}^{3} / \mathrm{h}$ [8].The heating mode of the system (applicable during winter) is investigated in this study. An energy storage density of $135 \mathrm{kWh} / \mathrm{m}^{3}\left(0.5 \mathrm{GJ} / \mathrm{m}^{3}\right)$ can be obtained in the heating mode of the storage [13].

The following assumptions are made in this investigation:

- The maximum storage capacity is utilizable in the charging process.

- The formula for zeolite $13 \mathrm{X}$ is $\mathrm{Na}_{2}$ $\mathrm{O} . \mathrm{Al}_{2} \mathrm{O}_{3} \cdot 3 \mathrm{SiO}_{2} \cdot 6 \mathrm{H}_{2} \mathrm{O}$.

- Zeolite 13X has a maximum water uptake during the charging process and dried zeolite $13 \mathrm{X}$ hydrates have the maximum number of water molecules.

- The maximum volumetric air flow rate $\left(6000 \mathrm{~m}^{3} / \mathrm{h}\right)$ occurs during charging and discharging.

- The energy changes during adsorption and desorption are equal in magnitude, i.e. $\Delta H_{a d}=-\Delta H_{d s}$.

- The exergy changes during adsorption and desorption are equal in magnitude, i.e. $\Delta \in a d=-\Delta \in d s$.

- Properties of dry air are considered for the air as the working fluid.

The effect of the assumptions made in this study can be investigated on the efficiency results. It is particularly important to note that in this investigation the maximum storage capacity is considered and the volumetric air flow rate during charging and discharging processes is assumed to have its maximum value. With additional practical data, these values may vary and efficiencies and other results will change correspondingly.

\subsection{Charging Process}

The thermochemical storage is charged when energy is available from the district heating system in off-peak hours. 


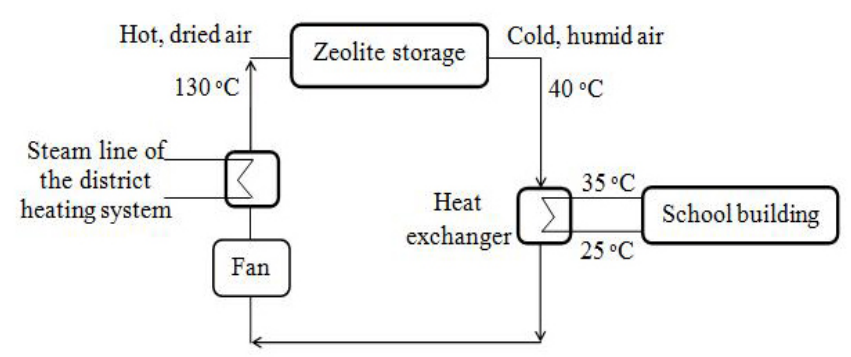

Fig. (3). Charging (desorption) process at night. Adapted from [11].

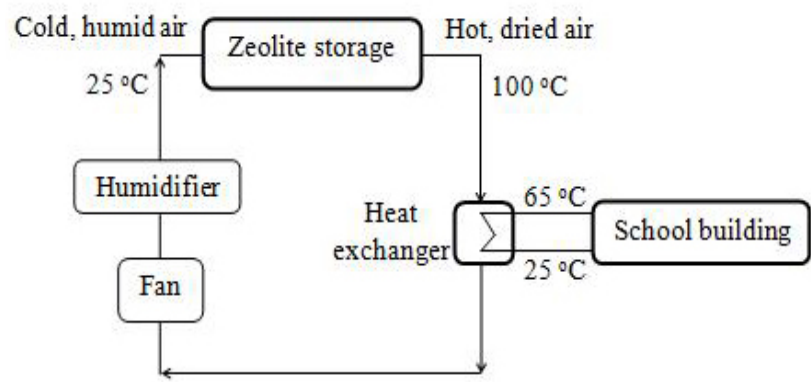

Fig. (4). Discharging (adsorption) process during the day. Adapted from [11].

Charging is performed during 10 hours nightly (from 9 p.m. to 7 a.m.) each day.

The charging process is illustrated in Fig. (3). At first the air is heated from $25{ }^{\circ} \mathrm{C}$ to $130{ }^{\circ} \mathrm{C}$ by the district heating system. At night, the zeolite is charged using the air. Under these conditions zeolite is dried and the waste heat of the charging process at a temperature level of 35 to $40{ }^{\circ} \mathrm{C}$ supplies the heating system of the school. The maximum storage capacity of the charging process is $1400 \mathrm{kWh}$ at a charging temperature of $130{ }^{\circ} \mathrm{C}$ [11]. As noted earlier, it is assumed that the maximum storage capacity can be obtained during charging. Temperatures and the maximum storage capacity are optimistic according to the design conditions.

\subsection{Discharging Process}

The thermochemical storage is discharged during daytime (the peak period). The discharging process is illustrated in Fig. (4). Air is heated to $25{ }^{\circ} \mathrm{C}$ and saturated with water vapor by a humidifier. Then, the saturated air is blown through the storage of dried zeolite. The air temperature rises to $100{ }^{\circ} \mathrm{C}$. Discharging occurs over 14 hours (from 7 a.m. to 9 p.m.) each day and can provide a maximum heating power of $95 \mathrm{~kW}$ at an outdoor temperature of $-16^{\circ} \mathrm{C}$ [11].

\subsection{Energy Analysis of TES Processes}

Energy efficiencies are determined for the charging and discharging processes for the considered thermochemical TES, as well as for the overall process. Note that the energy efficiency for the storing period is not discussed extensively, as it is $100 \%$.

\subsubsection{Charging}

The charging energy efficiency can be calculated using Equation (5). We calculate the energy efficiency of each process as the ratio of the useful energy output to the energy input as follows:

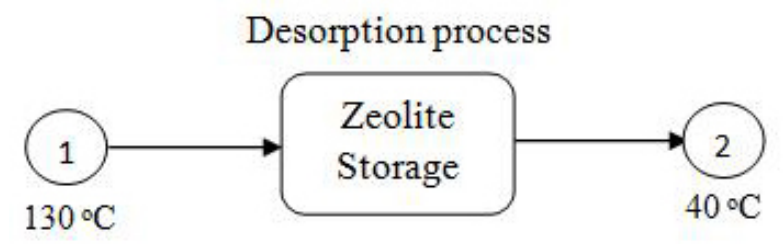

Fig. (5). Desorption process with inlet and outlet conditions of the air stream.

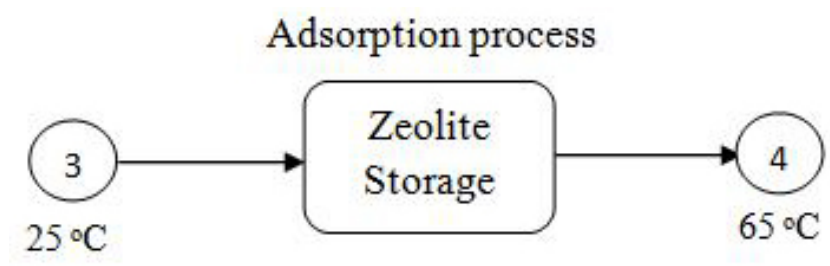

Fig. (6). Adsorption process with inlet and outlet conditions of the air stream.

$\eta_{c}=\frac{\text { useful output energy }}{\text { input energy }}$

In this analysis, the zeolite storage is taken to be the control volume (see Fig. 5). In the charging process, the useful output energy is equal to the storage capacity of the charging process, which is $1400 \mathrm{kWh}$ (or 5,040,000 kJ).

The input energy is supplied by the air flow and can be calculated as

$\mathrm{Q}_{\text {in }}=m_{c} C_{p}\left(T_{1}-T_{2}\right)$

Here, $m_{c}$ is the mass of air which blows through the storage during the charging period and can be calculated as

$m_{c}=q_{c} t_{c} \rho_{c}$

where $q_{c}$ denotes the volumetric air flow rate, and $t_{c}$ and $\rho_{c}$ are charging time and air density, respectively. The density and specific heat at constant pressure $C_{p}$ of the air are evaluated at the mean temperature of the inlet and outlet air (85 $\left.{ }^{\circ} \mathrm{C}\right)$. Thus,

$\mathrm{m}_{\mathrm{c}}=6000 \mathrm{~m}^{3} / \mathrm{h} \times 10 \mathrm{~h} \times 0.99 \mathrm{~kg} / \mathrm{m}^{3}=59,400 \mathrm{~kg}$

So, the input energy is

$\mathrm{Q}_{\text {in }}=59,400 \times 1.009 \times(130-40)=5,394,114 \mathrm{kj}$

The useful output energy is 5,040,000 kJ and the charging energy efficiency is:

$\eta_{c}=\frac{\text { useful output energy }}{\text { input energy }}=\frac{5,040,000}{5,394,114}=0.93$

Comparing Equations (5) and (20), it is observed that the energy gained in the desorption process is equal to the numerator of the efficiency equation $(5,040,000 \mathrm{~kJ})$. Since the reaction is reversible, the energy released during the adsorption process is $5,040,000 \mathrm{~kJ}$ as well.

\subsubsection{Discharging}

The discharging energy efficiency is calculated using Equation (11). In this analysis, the zeolite storage is taken to be the control volume (see Fig. 6).

The recovered energy can be calculated as 
Table 1. Evaluating Standard Chemical Exergy of Selected Components for Normal Reference-Environment Conditions $\left(T_{0}=\right.$ $\left.298.15 \mathrm{~K} ; \mathrm{P}_{0}=101.325 \mathrm{kPa}\right)$

\begin{tabular}{|c|c|c|c|c|c|c|}
\hline Compound & $\begin{array}{c}\Delta \mathbf{G}_{\mathbf{f}} \\
\mathbf{k J J} / \mathbf{m o l}\end{array}$ & \multicolumn{2}{|c|}{$\mathbf{n}_{\mathbf{e}}$} & \multicolumn{2}{c|}{$\begin{array}{c}\boldsymbol{\varepsilon}_{\text {chne }} \\
(\mathbf{k J J} / \mathbf{m o l})\end{array}$} & $\begin{array}{c}\boldsymbol{\varepsilon}_{\text {chne }} \\
(\mathbf{k J} / \mathbf{m o l})\end{array}$ \\
\hline \hline $\mathrm{Na}_{2} \mathrm{O}$ & -262.05 & $2(\mathrm{Na})$ & $0.5\left(\mathrm{O}_{2}\right)$ & $\begin{array}{c}336.6 \\
\mathrm{Na}\end{array}$ & $3.97\left(\mathrm{O}_{2}\right)$ & 413.14 \\
\hline $\mathrm{AI}_{2} \mathrm{O}_{2}$ & -1582.19 & $\begin{array}{c}2 \\
(\mathrm{AI})\end{array}$ & $1.5\left(\mathrm{O}_{2}\right)$ & $\begin{array}{c}988.2 \\
\mathrm{AI}\end{array}$ & $3.97\left(\mathrm{O}_{2}\right)$ & 400.17 \\
\hline $\mathrm{SiO}_{2}$ & -851.18 & $\begin{array}{c}1 \\
(\mathrm{Si})\end{array}$ & $\begin{array}{c}1 \\
\left(\mathrm{O}_{2}\right)\end{array}$ & $\begin{array}{c}854.9 \\
\mathrm{Si}\end{array}$ & $3.97\left(\mathrm{O}_{2}\right)$ & 7.69 \\
\hline $\mathrm{H}_{2} \mathrm{O}$ (gas) & -228.75 & $\begin{array}{c}1 \\
\left(\mathrm{H}_{2}\right)\end{array}$ & $0.5\left(\mathrm{O}_{2}\right)$ & $236.09\left(\mathrm{H}_{2}\right)$ & $3.97\left(\mathrm{O}_{2}\right)$ & 9.32 \\
\hline $\mathrm{H}_{2} \mathrm{O}$ (liquid) & -237.32 & $\begin{array}{c}1 \\
\left(\mathrm{H}_{2}\right)\end{array}$ & $0.5\left(\mathrm{O}_{2}\right)$ & $236.09\left(\mathrm{H}_{2}\right)$ & $3.97\left(\mathrm{O}_{2}\right)$ & 0.76 \\
\hline
\end{tabular}

Taken from [16].

$\mathrm{Q}_{\mathrm{rec}}=m_{d} C_{p}\left(T_{4}-T_{3}\right)$

The quantity $m_{d}$ is the mass of air which passes through the storage during the discharging period and can be calculated as

$m_{d}=q_{d} t_{d} \rho_{d}$

Here, $\mathrm{q}_{\mathrm{d}}$ denotes the volumetric air flow rate. $t_{d}$ and $\rho_{d}$ are discharging time and density of air, respectively. The density and $C_{p}$ of the air are evaluated at the mean temperature of the inlet and outlet air $\left(45^{\circ} \mathrm{C}\right)$, thus

$\mathrm{m}_{\mathrm{d}}=600 \mathrm{~m}^{2} / \mathrm{h} \times 1.106 \mathrm{~kg} / \mathrm{m}^{2}=92.904 \mathrm{~kg}$

Thus,

Qres $=92,9904 \times 1.006 \times 40=3,738,457 \mathrm{~kJ}$

The discharging energy efficiency is

$\eta_{\mathrm{d}}=\frac{3,738,457}{4,040,000}=0.74$

\subsubsection{Overall TES Process}

The energy efficiency of the overall TES process can be calculated using Equation (17):

$\eta_{0}=\frac{\text { Qrec }}{\text { Qin }}=\frac{3,738,457}{5,394,114}=0.69$

\subsection{Exergy Analysis of TES Processes}

Charging, discharging and overall exergy efficiencies are determined for the considered thermochemical TES. As before, the exergy efficiency for the storing period (100\%) is not discussed extensively.

\subsubsection{Charging}

The exergy efficiency of the charging process can be evaluated using Equation (9). During charging, air is heated from $40{ }^{\circ} \mathrm{C}$ to $130{ }^{\circ} \mathrm{C}$. The exergy input for the charging process can be evaluated as

$$
\epsilon_{\text {in }}=\text { Net exergy delivered by air }=m_{c} \quad\left[h_{2}-h_{1}-T_{0}\left(s_{2}-s_{1}\right)\right]
$$

where $h_{1}$ and $h_{2}$ denote the specific enthalpy of the air at the input and output conditions, $S_{1}$ and $S_{2}$ denote the specific entropy of the air at the input and output conditions. The relevant properties of the air are as follows:
- $\quad h_{1}=338.8 \mathrm{~kJ} / \mathrm{kg}\left(\right.$ at $\left.T_{1}=65^{\circ} \mathrm{C}, P_{4}=101 \mathrm{kPa}\right)$

- $\quad S_{1}=5.746 \mathrm{~kJ} / \mathrm{kg}\left(\right.$ at $\left.T_{1}=4^{\circ} \mathrm{C}, P_{1}=101 \mathrm{kPa}\right)$

- $\quad h_{2}=6 \mathrm{~kJ} / \mathrm{kg} \mathrm{K}\left(\right.$ at $\left.T_{2}=130^{\circ} \mathrm{C}, P_{2}=101 \mathrm{kPa}\right)$

- $\quad S_{2}=6 \mathrm{~kJ} / \mathrm{kg} \mathrm{K}\left(\right.$ at $\left.T_{2}=130^{\circ} \mathrm{C}, P_{2}=101 \mathrm{kPa}\right)$

The exergy input in the charging process can be calculated using Equation (32):

$\in_{\text {in }}=60,240 \times[404.5-313.16-298 \times(6-5.746)]=942,635 \mathrm{k}$

To determine the exergy change during a thermochemical reaction, we calculate the exergy of reactants before the reaction as well as the exergy of products after the reaction. The difference between these two quantities is the exergy change within the control volume over the period of the reaction. The exergy of the control volume before the reaction is the sum of the exergies of the reactants. This exergy includes the physical, potential, kinetic and chemical exergy components of the reactants. As pointed out earlier, potential and kinetic exergy are neglected and also the physical exergy change of the components can often be neglected relative to their chemical exergy changes. This assumption is applied in this analysis. Consequently, we need only focus on the chemical exergy of the reactants.

The chemical exergy of compounds can be determined following the treatment $[14,15]$. The standard chemical exergy of a chemical compound $h_{1}$ can be calculated by means of the exergy balance for a reversible reaction:

$\in{ }^{c h n}=\Delta G_{f}+\sum_{e} n_{e} \in$ chne

Here, $\Delta G_{f}$ denotes the Gibbs energy of formation, $n_{e}$ the amount of element $e$ (in $\mathrm{kmol}$ ), and $\in$ chne the standard chemical exergy of the element.

A typical chemical formula for zeolite $13 \mathrm{X}$ composition is $\mathrm{Na}_{2} \mathrm{O} \cdot \mathrm{Al}_{2} \mathrm{O}_{3} \cdot\left(2.8 \pm 0.2\left(\mathrm{Sio}_{2} \cdot(6 \sim 7) \mathrm{H}_{2} \mathrm{O}\right.\right.$. We assume the formula for zeolite $13 \mathrm{X}$ in this study as $\mathrm{Na}_{2} \mathrm{O} \cdot \mathrm{Al}_{2} \mathrm{O}_{3} \cdot 3 \mathrm{SiO}_{2} \cdot 6 \mathrm{H}_{2} \mathrm{O}$. The molecular weight for zeolite $13 \mathrm{X}$ is 452.3 grams. There are $7000 \mathrm{~kg}$ of zeolite in the storage system, so the numbers of moles of zeolite $13 \mathrm{X}$ is 15,476 . The charging reaction can be expressed as

$\mathrm{Na}_{2} \mathrm{O} . \mathrm{Al}_{2} \mathrm{O}_{3} .3 \mathrm{SiO}_{2} .6 \mathrm{H}_{2} \mathrm{O}+$ heat $\rightarrow \mathrm{Na}_{2} \mathrm{O} . \mathrm{Al}_{2} \mathrm{O}_{3} .3 \mathrm{SiO}_{2}+6 \mathrm{H}_{2} \mathrm{O}$ 


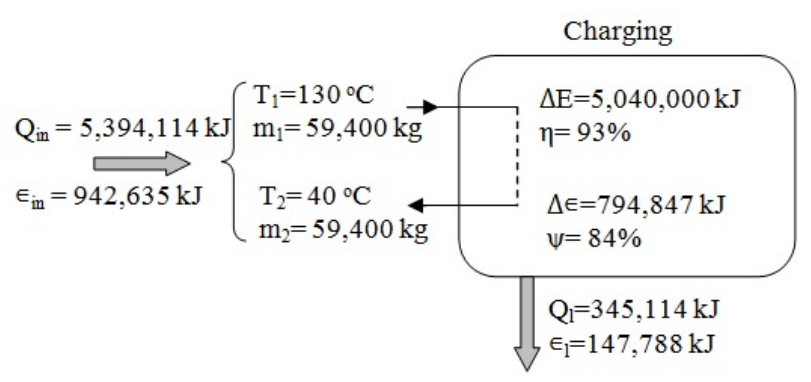

Fig. (7). The charging process, showing energy and exergy parameter values.

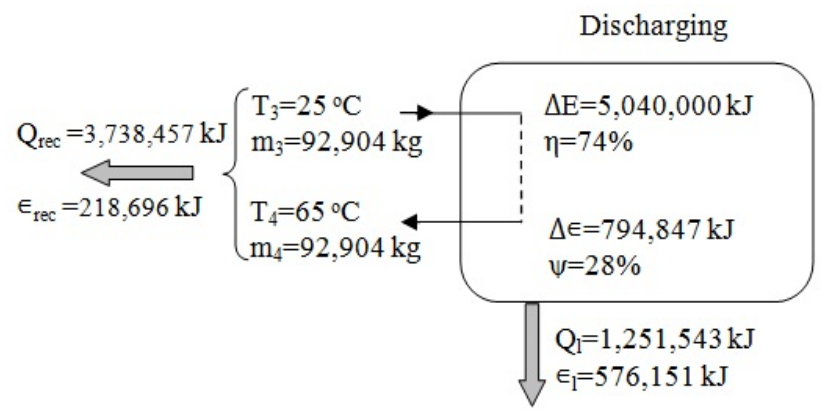

Fig. (8). The discharging process, showing energy and exergy parameter values.

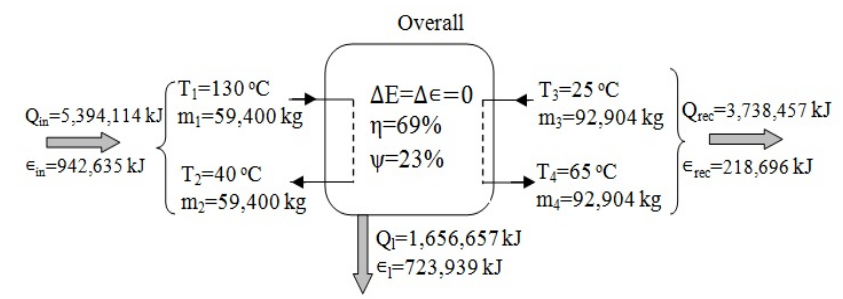

Fig. (9). The overall storage process, showing energy and exergy parameter values.

In order to calculate the exergy stored in this reaction, we need to evaluate the standard chemical exergy of each component (see Table 1). The standard chemical exergy of a chemical compound $\in$ chn can be calculated by means of the exergy balance for a reversible reaction.

Using calculated data from Table 1, the standard chemical exergy of zeolite $13 \mathrm{X}$ (before and after desorption) can be calculated as follows. For $\mathrm{Na}_{2} \mathrm{O}_{2} \mathrm{Al}_{2} \mathrm{O}_{3} .3 \mathrm{SiO}_{2} .6 \mathrm{H}_{2} \mathrm{O}$ :

$$
\in_{c h n}=413.14+400.17+(3 \times 7.69)+(6 \times 0.76)=840.94 \mathrm{~kJ} / \mathrm{mol}
$$

For: $\mathrm{Na}_{2} \mathrm{O} \cdot \mathrm{Al}_{2} \mathrm{O}_{3} \cdot 3 \mathrm{Sio}_{2}$

$$
\in \mathrm{chn}=413.14+400.17+(3 \times 7.69)=836.38 \mathrm{kj} / \mathrm{mol}
$$

The exergy accumulation during the charging period can be expressed as

Exergy stored in desorption $=\in$ tot, products $-\in$ tot, reactants

Here, $\mathrm{Na}_{2} \mathrm{O} \cdot \mathrm{Al}_{2} \mathrm{O}_{3} \cdot 3 \mathrm{SiO}_{2}$ and $\mathrm{H}_{2} \mathrm{O}$ are products and $\mathrm{Na}_{2} \mathrm{O} \cdot \mathrm{Al}_{2} \mathrm{O}_{3} \cdot 3 \mathrm{SiO}_{2} \cdot 6 \mathrm{H}_{2} \mathrm{O}$ is the reactant, and the corresponding standard chemical exergies of the products and the reactant have been calculated:

Exergy stored in desorption $=15,476$ moles $x\{[836.38 \mathrm{~kJ} / \mathrm{mol}+(6 \times 9.32)$ $\mathrm{kj} / \mathrm{mol}]-840.94 \mathrm{kj} / \mathrm{mol}\}$
Thus, the exergy efficiency of the charging process can be calculated as

$$
\Psi_{c}=\frac{\text { Exergy stored in desorption }}{\text { Exergy input }}=\frac{794,847}{942,635}=0.84
$$

\subsubsection{Discharging}

The exergy efficiency of the discharging process can be evaluated using Equation (15). During discharging, air is heated from $25{ }^{\circ} \mathrm{C}$ to $65^{\circ} \mathrm{C}$. The exergy recovered in this process can be evaluated as

Net exergy recovered by air $=\mathrm{m}_{\mathrm{d}}\left[\mathrm{h}_{4}-\mathrm{h}_{3}-\mathrm{T}_{0}\left(\mathrm{~S}_{4}-\mathrm{S}_{2}\right)\right]$

where $h_{3}$ and $h_{4}$ denote respectively the specific enthalpy of the air at the input and output conditions, and $S_{3}$ and $S_{4}$ respectively denote the specific entropy of the air at the input and output conditions. Thus, the relevant properties of the air are as follows:

- $\quad h_{3}=298.6 \mathrm{~kJ} / \mathrm{kg}\left(\right.$ at $\left.T_{3}=25^{\circ} \mathrm{C}, P_{3}=101 \mathrm{kPa}\right)$

- $\quad S_{3}=5.696 \mathrm{~kJ} / \mathrm{kg} \mathrm{K}\left(\right.$ at $\left.T_{3}=4^{\circ} \mathrm{C}, P_{3}=101 \mathrm{kPa}\right)$

- $\quad h_{1}=338.8 \mathrm{~kJ} / \mathrm{kg}\left(\right.$ at $\left.T_{1}=65^{\circ} \mathrm{C}, P_{4}=101 \mathrm{kPa}\right)$

- $S_{4}=5.823 \mathrm{~kJ} / \mathrm{kg} \mathrm{K}\left(\right.$ at $\left.T_{4}=65^{\circ} \mathrm{C}, P_{4}=101 \mathrm{kPa}\right)$

From Equation (41):

$\in$ rec $=92,904 \times[338.8-298.6-298 \times(5.823-5.696]=218,696 \mathrm{~kJ}$

So,

$\psi_{\mathrm{d}}=\frac{\text { Exergy recoverd by air }}{\text { Exergy released in adsorption }}=\frac{218,696}{794,847}=0.28$

\subsubsection{Overall TES Process}

The exergy efficiency of the overall TES process can be calculated using Equation (19):

$\psi 0=\frac{\in \text { rec }}{\epsilon \text { in }}=\frac{218,696}{794,847}=0.23$

\section{SUMMARY}

The energy and exergy analyses for the charging and discharging processes are summarized illustratively in Fig. (7), (8) and (9). Note that $\in l$ in these diagrams is the summation of the exergy loss and the exergy destruction.

\section{DISCUSSION}

The energy- and exergy-based methodology applied here is similar to that employed for analyses of other types of TES systems. General efficiency expressions are determined for the charging, storing and discharging processes, as well as the overall TES process. These efficiencies are calculated for an illustrative example, based on an actual system.

Exergy analysis is seen to be useful, when applied with or in place of energy analysis, for assessing efficiencies of the various processes occurring in open thermochemical TES systems as well as other aspects of their thermodynamic performances. Exergy analysis is more useful than energy analysis for identifying the locations and reasons of thermodynamic losses in a TES system and can assist efforts to improve or optimize designs. The energy loss of the overall process is $1,656,657 \mathrm{~kJ}$ and the exergy loss of the overall 
Table 2. Comparison of Efficiencies for Various Types of TES

\begin{tabular}{|c|c|c|c|c|}
\hline \multicolumn{2}{|c|}{ TES Type } & $\eta o$ & $\psi o$ & Remarks \\
\hline \multicolumn{2}{|c|}{ Sensible } & $70 \%$ & $40 \%$ & Aquifer TES [18] \\
\hline \multicolumn{2}{|c|}{ Latent } & $45 \%$ & $2.2 \%$ & $\mathrm{CaCl}_{2} \cdot 6 \mathrm{H}_{2} \mathrm{O}$ as PCM [19] \\
\hline \multirow{2}{*}{ Thermochemical } & Closed-loop & $50 \%$ & $9 \%$ & $\mathrm{SrBr}_{2} \cdot 6 \mathrm{H}_{2} \mathrm{O}$ as TCM [20] \\
\hline & Open-loop & $69 \%$ & $23 \%$ & Zeolite $13 \mathrm{X}$ as TCM [11] \\
\hline
\end{tabular}

storage system is $723,939 \mathrm{~kJ}$. It is seen in Figs. (7-9) that $76 \%$ of the total energy loss and $79 \%$ of the total exergy loss occur during discharging. So, optimizing the discharging process can help to improve the overall efficiency of the storage process.

Efficiencies of the storing process have been taken to be $100 \%$, based on the assumption that there is no energy loss during storing period. This assumption is likely reasonable, in that the materials stored are at ambient conditions so no heat losses are expected. Nonetheless, the storing-period efficiencies could be lower than $100 \%$, depending on the characteristics of the thermochemical material, the working fluid, the storing temperature, the storing duration, etc.

In this study, a single cycle of an open TES system operation is considered. Therefore, degradation of the thermochemical materials over time, as they undergo repeated cycles, is not considered. However, the effects of degradation are potentially significant, especially if repeated thermochemical cycles affect performance and the properties of the thermochemical material degrade notably over time. Little information on the degradation of thermochemical storage materials is available, but it is noted that phase change materials (PCMs) are also degraded with cycling in latent TES systems. Sari and Karaipekli investigated the characterization and thermal properties of palmitic acid/expanded graphite as a PCM in latent TES systems and showed that, after 3000 melting/freezing cycles, the melting latent heat decreased from $148.36 \mathrm{~kJ} / \mathrm{kg}$ to $140.38 \mathrm{~kJ} / \mathrm{kg}$ and freezing latent heat decreased from $149.66 \mathrm{~kJ} / \mathrm{kg}$ to $139.97 \mathrm{~kJ} / \mathrm{kg}$ [17].

A TES system for heating capacity only is investigated here. The system considered in the illustrative example supplies heat to a school building during winter or mid-season periods. The storage of cooling capacity is not considered.

For the illustrative example, the energy and exergy efficiencies respectively are determined to be $93 \%$ and $84 \%$ for the charging process and $74 \%$ and $28 \%$ for the discharging process. The results demonstrate that the energy efficiency of the discharging process is higher than the corresponding efficiency for the charging process and that the exergy efficiency of the charging process is higher than the corresponding efficiency for the discharging process. The overall energy and exergy efficiencies are found to be $69 \%$ and $23 \%$, respectively. The results demonstrate that the exergy efficiencies of the charging, discharging, and overall processes are higher than the corresponding energy efficiencies. Exergy analysis takes into account the loss of availability of energy in storage operations and it reflects the thermodynamic and economic value of the storage operation. In the analyses, the maximum flow rate has been considered for the air and also it has been assumed that zeolite $13 \mathrm{X}$ is dried during desorption process to the maximum extent possible.
Therefore, the energy gained by the adsorbent attains a maximum value. The same assumption has been made for the adsorption process.

Exergy analysis takes into account the loss of availability of energy in a thermochemical TES system and indicates the thermodynamic and economic value of the system. The differences between energy and exergy efficiencies for the thermochemical TES and its processes are dependent on various factors, including the thermodynamic properties of the working fluid (air) and the thermochemical material, the nature of the desorption or adsorption process, the maximum output temperature of the heat source (a district heating system in the case study). The TES energy or exergy losses likely vary with all of these factors and others.

The factors discussed above suggest that the performance attained with other types of TES (sensible and latent) may be attained with open thermochemical TES, but with more compact storage systems. Efficiencies of various types of TES systems are compared in Table 2.

\section{CONCLUSIONS}

The thermodynamic analysis presented here of an open thermochemical TES allows energy and exergy efficiencies for the overall TES and its processes, as well as other performance measures, to be determined and better understood. Exergy analysis is particularly useful for specifying the locations and reasons of thermodynamic losses in TES systems. Energy and exergy analyses help understand and contrast efficiencies for the various processes occurring in TES systems and thereby assist efficiency improvement efforts. The results presented here suggest that further research is needed to improve understanding of open thermochemical TES. The results suggest that open thermochemical TES may be as efficient other types of TES but more compact. For decision making regarding the selection of thermochemical TES for a particular application, other factors beyond the thermodynamic ones considered here need to be assessed, including the environmental effects of the TES system, economics, the degradation of the thermochemical material over time as well as its cycling behavior, the reliability of the overall system and required maintenance. Feasibility studies that consider these factors for specific applications appear to be merited.

\section{NOMENCLATURE}

$\begin{array}{lll}C p & = & \text { specific heat at constant pressure }(\mathrm{kJ} / \mathrm{kgK}) \\ E & = & \text { energy }(\mathrm{kJ}) \\ h & = & \text { specific enthalpy }(\mathrm{kj} / \mathrm{kg}) \\ m & = & \text { mass of working fluid }(\mathrm{kg})\end{array}$


$P \quad=\quad$ pressure $(\mathrm{kPa})$

$Q=$ heat $(\mathrm{kJ})$

$s \quad=\quad$ specific entropy $(\mathrm{kJ} / \mathrm{kgK})$

$T=$ temperature $\left({ }^{\circ} \mathrm{C}\right.$ or $\left.\mathrm{K}\right)$

$V \quad=\quad$ volume $\left(\mathrm{m}^{3}\right)$

\section{SUBSCRIPTS}

$\begin{array}{lll}0 & = & \text { reference environment } \\ \text { ad } & = & \text { adsorption } \\ d s & = & \text { desorption } \\ D & = & \text { destruction } \\ e & =\text { element } \\ \text { in } & =\text { input } \\ l & =\text { loss } \\ o & =\text { overall } \\ \text { rec } & =\text { recovered } \\ \text { tot } & = & \text { total }\end{array}$

\section{GREEK LETTERS}

$\begin{array}{lll}\Delta G_{f} & =\text { Gibbs energy of formation }(\mathrm{kJ} / \mathrm{mol}) \\ \Delta E & = & \text { energy accumulation }(\mathrm{kJ}) \\ \Delta \in & = & \text { exergy accumulation }(\mathrm{kJ}) \\ \in & = & \text { exergy }(\mathrm{kJ}) \\ \in_{c h n} & =\begin{array}{l}\text { standard chemical exergy of a compound } \\ (\mathrm{kJ} / \mathrm{mol})\end{array} \\ \in_{\text {chne }} & =\begin{array}{l}\text { standard chemical exergy of an element } \\ (\mathrm{kJ} / \mathrm{mol})\end{array} \\ \eta & =\text { energy efficiency }(-) \\ \rho & =\text { density }\left(\mathrm{kg} / m^{3}\right) \\ \Psi & =\text { exergy efficiency }(-)\end{array}$

\section{CONFLICT OF INTEREST}

The authors confirm that this article content has no conflicts of interest.

\section{ACKNOWLEDGEMENT}

The authors gratefully acknowledge the financial support provided by the Natural Sciences and Engineering Research Council of Canada.

\section{REFERENCES}

[1] Rahm, D. Sustainable Energy and the States, Essay on Politics Markets and Leadership, $1^{\text {st }}$ ed.; McFarland: North Carolina, 2002.

[2] Rasthal, J.E.; Drennen, T.E. Pathways to a Hydrogen Future, $3^{\text {rd }}$ ed.; Elsevier: UK, 2007.

[3] Fuglestvedt, J.S.; Hailemariam, K.; Stuber, N. Alternatives to the global warming potential for comparing climate impacts of emissions of greenhouse gases. Clim. Change, 2005, 68 (3), 281-302.

[4] International Energy Agency (IEA). Compact Thermal Energy Storage: Material Development and System Integration. Annex text (draft), Task 42, Annex 28, Solar Heating and Cooling Programme, 2008.

B] Bales, C. Thermal Properties of Materials for Thermo-chemical Storage of Solar Heat. Available at: http://www.ieashc.org/publications/downloads/task32-Thermal_Properties_of_Materials.pdf [Accessed 24/05/2010], 2005.

6] Hauer, A. Sorption Storage for solar Thermal Energy - Possibilities and Limits. Proceedings of Eurosun 2008: 1st International Conference on Solar Heating, Cooling and Buildings, October 7-10, Lisbon, Portugal, 2008.

Hauer, A.; Lavemann, E. Open Absorption Systems for Air Conditioning and Thermal Energy Consumption, Part VI, In: Thermal Energy Storage for Sustainable Energy Consumption, Paskoy, H.O. ed.; Springer: Netherlands, 2007, pp.429-444.

] Hauer, A. Evaluation of adsorbent materials for heat pump and thermal energy storage applications in open systems. Adsorption, 2007, 13 (3-4), 399-405.

[9] Edem, NT K.; Liu, H.; Le Pierre, N; Luo, L. A review on long-term sorption solar energy storage. Renewable Sustainable Energy Rev., 2009, 13 (9), 2385-2396.

[10] Bales, C. Chemical and Sorption Heat storage. Proceedings of DANVAK Seminar, DANVAK Seminar (Solar Heating Systems Combisystems - Heat Storage), November 14, Lyngby, Denmark, 2006.

[11] Hauer, A. Thermal Energy Storage with Zeolite for Heating and Cooling Applications. Proceedings of 3rd Workshop of Annex 17 ECES IA/IEA, Tokyo, Japan, October 1-2, 2002.

[12] Dincer, I.; Rosen, M.A. Thermal Energy Storage: Systems and Applications, $2^{\text {nd }}$ ed.; Wiley: UK, 2011.

[13] Fischer, S.; Hauer, A. Space Heating and Cooling with a Thermochemical Storage System in the District Heat Net of Munich. Proceedings of IEA Annex 10, Phase Change Materials and Chemical Reactions for Thermal Energy Storage, Second Workshop, Sofia, Bulgaria, November, 1998.

[14] Szargut, J. International progress in second law analysis. Energy, 1980, 5 (8-9), 709-718.

[15] Szargut, J. Chemical exergies of the elements. Appl. Energy, 1989, 32 (4), 269-286.

[16] Woods, T.L.; Garrels, R.M. Thermodynamic Values at Low Temperatures for Natural Inorganic Materials: An Uncritical Summary; Oxford University Press: New York, 1987.

[17] Sari, A.; Karaipekli, A. Preparation, thermal properties and thermal reliability of palmic acid/expanded graphite composite as formstable PCM for thermal energy storage. Sol. Energy Mater. Sol. Cells, 2009, 93 (5), 571-576.

[18] Rosen, M.A. Second-law analysis of aquifer thermal energy storage systems'. Energy, 1999, 24 (2), 167-182.

[19] Koca, A.; Oztop, H.; Koyun, T.; Varol, Y. Energy and exergy analysis of a latent heat storage system with phase change material for a solar collector'. Renewable Energy, 2008, 33 (4), 567-574.

[20] Mauran, S.; Lahmidi, H.; Goetz, V. Solar heating and cooling by a thermochemical process: first experiments of a prototype storing 60 kWh by a solid/gas reaction. Solar Energy, 2008, 82 (7), 623-636.

(C) Abedin and Rosen; Licensee Bentham Open.

This is an open access article licensed under the terms of the Creative Commons Attribution Non-Commercial License (http://creativecommons.org/licenses/by-nc/3.0/) which permits unrestricted, non-commercial use, distribution and reproduction in any medium, provided the work is properly cited. 